\title{
Analyzing Student Perceptions on Translanguaging: A Case Study of a Puerto Rican University Classroom
}

\section{Percepciones del translenguaje según los estudiantes de la Universidad de Puerto Rico: un estudio de caso*}

\author{
Adrian J. Rivera \\ riveaj02@ipfw.edu \\ Indiana University - Purdue University, Fort Wayne, USA \\ Catherine M. Mazak \\ catherine.mazak@upr.edu \\ University of Puerto Rico, Mayagüez, Puerto Rico
}

Translanguaging in the classroom is gaining traction as a viable pedagogical choice. Often overlooked, though, are the students' attitudes in response to strategic classroom translanguaging. This study seeks to determine whether students' language attitudes influence their perceptions of an instructor's translingual pedagogy. The study took place in an undergraduate psychology classroom at the University of Puerto Rico, Mayagüez, and involved a case-study approach and analysis of survey results. The results show this particular group of students has a neutral to positive outlook on classroom translanguaging. The high number of neutral responses may mean students are indifferent to translingual pedagogy or that these students are conditioned to work within a context where code switching and translanguaging happen frequently.

Key words: Language attitudes, translanguaging, translingual pedagogy.

El uso del translenguaje como alternativa viable en el salón de clases está cada día siendo más aceptado. Sin embargo, las actitudes de los estudiantes hacia el translenguaje no han sido investigadas.

Received: June 9, 2016. Accepted: November 9, 2016.

How to cite this article (APA 6th ed.):

Rivera, A. J., \& Mazak, C. M. (2017). Analyzing student perceptions on translanguaging: A case study of a Puerto Rican university classroom. HOW, 24(1), 122-138. http://dx.doi.org/10.19183/how.24.1.312.

This article is licensed under a Creative Commons Attribution-NonCommercial-NoDerivatives 4.0 International License. License Deed can be consulted at http://creativecommons.org/licenses/by-nc-nd/4.0/. 
El presente artículo busca determinar si la implementación pedagógica del translenguaje influye en las actitudes de los estudiantes. Este estudio tuvo lugar en un curso de psicología de la Universidad de Puerto Rico en Mayagüez usando la metodología de estudio de caso y análisis de cuestionarios. Los resultados muestran que se mantiene una postura neutral o positiva respecto al translenguaje que ocurre en el aula. La gran cantidad de respuestas neutrales puede indicar que los estudiantes son indiferentes a la pedagogía del translenguaje o que ésta no se considera extraordinaria porque los estudiantes suelen interactuar en un contexto donde el translenguaje y la alternancia de código ocurren frecuentemente.

Palabras clave: actitudes lingüísticas, pedagogía del translenguaje, translenguaje.

\section{Introduction}

In bilingual or multilingual classrooms, the instructor's choice of which language to use is an important factor for improving student understanding. These choices are obviously affected by language policy or the rules of a given educational institution. On a subtler level, the choice of language can be influenced by the educator's language attitudes. These language attitudes can be potentially detrimental for students around the world; for instance, the instructor's language beliefs can lead to an unfair prejudice towards or against certain languages. On the other hand, the use of multiple languages in the classroom may benefit the students' learning, depending on the needs of the student and the goals the educators are pursuing.

The Puerto Rican educational system is a good example of how multiple languages can be utilized in the classroom. Puerto Rico presently holds both Spanish and English as official languages, though the focus on education using these languages varies depending on the age and educational level of the students. This is likely a result of the last few generations being educated in schools providing opportunities for bilingual instruction. Unfortunately, the policies that regulate such teaching have been inconsistent. For over 100 years, the educational system of Puerto Rico has treated Spanish and English as separate entities, and policies mandating either English-medium or Spanish-medium instruction have alternated many times.

One result of these changing policies for teaching language is Puerto Rico's multilingual and diverse population. Census data show that $95.3 \%$ of Puerto Ricans report having knowledge of two or more languages. However, this number encompasses residents of all proficiency levels and, of these people, 84.6\% self-identify as speaking English "less than very well" ("Census 2010 Total Population,” n.d.). Many variables can lead us to question the reliability of these data, particularly the self-reporting and self-assessment involved; we cannot be certain that those in the categories of "speak [ing] English very well" or "speak[ing] English less than very well" actually belonged there. Language proficiency may be stronger 
(or weaker) than the people are willing to admit. This should be remembered when planning an educational curriculum.

Therefore, for educators and students alike, it may prove useful to de-stigmatize the ideology of using both English and Spanish as instructional tools, particularly in contentbased courses. To begin to meet the needs of these bilingual students, this study seeks to determine the language attitudes of a select class of undergraduate students from a university in a largely bilingual context. This class is notable because the instructor utilizes a flexible bilingual pedagogy, and gives students a great deal of freedom in the languages they use in both oral and written work. However, in an environment where monolingual language beliefs can be prevalent and restricting, students may not always respond favorably to a flexible bilingual pedagogy.

With this in mind, the following study seeks to determine how students perceived an instructor's choice of implementing a flexible translingual pedagogy. This study focuses on the language attitudes and opinions of students in a Puerto Rican university classroom at a public university known for its science and engineering programs, the University of Puerto Rico, Mayagüez (UPRM).

\section{Translanguaging in the Classroom}

Terminology to address the use of multiple languages and the effects of utilizing multiple languages in education has been created, revised, and debated. This includes the terms "bilingual" and "multilingual," which can be viewed as one having proficiency in two or more languages, respectively. These labels continue to enforce the belief that languages are separate entities with finite boundaries. However, in recent years, the use of the prefix trans- has sought to blur these boundaries. Whereas "multilingual" views languages in an additive manner (the use of multiple, separate languages), "translingual" refers to "synergy, treating languages as ... mutually influencing each other" (Canagarajah, 2013, p. 41). Further, García (as cited in García \& Li, 2014) defines translanguaging as "multiple discursive practices in which bilinguals engage in order to make sense of their bilingual worlds," and mentions that it is "the discursive norm in bilingual families and communities" (p. 23).

Sayer (2013) believes that translanguaging is better understood as a descriptive label for bilingual practices of discourse that students and teachers use for both academic and non-academic purposes. The integration of translanguaging practices has been suggested as being a way to provide a scaffolding approach to instruction (García \& Sylvan, 2011). Sayer (2013) recommends that educators implement such practices by recognizing and 
utilizing the students' native languages as teaching tools via the various opportunities which translanguaging approaches afford.

A prominent strategy of incorporating translanguaging is the use of codemeshing. This strategy can be described as a "communicative device used for specific rhetorical and ideological purposes [where] a multilingual speaker intentionally integrates local and academic discourse as a form of resistance, reappropriation, and/or transformation of the academic discourse" (Michael-Luna \& Canagarajah, 2008, p. 56). In written discourse, code meshing is considered "a form of writing in which multilinguals merge their diverse language resources with the dominant genre conventions to construct hybrid texts for voice" (Canagarajah, 2013 , p. 40), offering a unique way for the writer's voice to be preserved in his or her work. Ultimately, such integration of the students' native languages and/or other non-standard varieties of English they use could potentially lead to a greater sense of ownership within the learning process and foster a stronger sense of identity.

The majority of available literature regarding classroom translanguaging is relatively recent, and has focused on the effects of utilizing these practices in the early stages of education, particularly in elementary school (e.g., Sayer, 2013). Interestingly, these methods of education are frequently used simply as the means to an end; students are permitted to use their native languages and are educated using these languages in tandem with the target language. However, once language proficiency in English is satisfactorily attained, the students are then transitioned into mainstream classrooms where their monolingual peers have been educated (Sayer, 2013). Even if native language education is maintained, it is often of a poor quality due to a lack of quality learning materials in local languages and/or a discrepancy between the home languages of students and teachers (Klapwijk \& Van der Walt, 2016). The result can be feelings of inferiority or unfairly and unnecessarily emphasizing the new language over their home one.

\section{The Role of Student Attitudes}

Language attitudes are defined as "any affective, cognitive, or conative index of evaluative reactions toward different languages or their speakers" (Ryan et al. as cited in Kircher, 2016, p. 241). These attitudes can manifest as a "range of different behaviors, including the decision of which language(s) to learn, which language(s) to use as one's main means of communication" (Kircher, 2016, p. 241) and can ultimately contribute to either language shift or language maintenance. Many factors contribute to student language attitudes, including use and familiarity with the target language, stereotypes regarding the language, and the students' future goals (Galloway as cited in Muthanna \& Miao, 2015). As these attitudes affect how native speakers and language learners view languages, it makes sense that they may affect how students learn. Further, the language ability of students can 
affect their attitudes towards learning in a particular language (Muthanna \& Miao, 2015). If the student has a negative attitude towards the target language, then their language ability may be affected (Sze-yan as cited in Muthanna \& Miao, 2015). However, the topic of language attitudes is one that has not been really explored in the emerging body of translanguaging literature.

Language attitudes are considered to have two dimensions: "status and solidarity" (Kircher, 2016, p. 241). For multilinguals, this means that one language may be associated with family and community, while another may be viewed as being more important for social and professional mobility. In most cases, this language of status is English, as it is a worldwide language of commerce and communication. This difference in language attitudes can cause a discrepancy in how languages are dealt with in the classroom. Assuming students are instructed with methods grounded in the belief that languages are separate entities, and that English is a superior language in the field of science or their chosen discipline, then it is possible they will not be open to translingual methods regardless of how potentially helpful they could be. As Kircher (2016) noted, knowledge about language attitudes is fundamental to the formulation of effective language planning measures, and without such knowledge, it is impossible to predict which measures will be successful and which will fail. Theorizing and having the best intentions will mean nothing unless students are receptive to the instruction methods being utilized.

Another issue affecting the use of translanguaging in the classroom pertains to how language is taught at the various levels of one's education. From the beginning of a bi- or multilingual's academic career, an ideology of language treating one's linguistic repertoire as being composed of separate and unique languages is likely imposed. In fact, much of the early literature on bilingualism notes the vitality of "keeping the two languages apart" (Haugen as cited in García \& Li, 2014, p. 12). The use of multiple languages was essentially stigmatized as a potential cause of detrimental language interference (García \& $\mathrm{Li}, 2014)$. An ideology such as this can be difficult to break free from; if one is conditioned to disapprove of mixing languages, then this mindset will carry over into one's continued education. However, expressing one's beliefs and enacting them are two very different things. It is possible that students who are opposed to translanguaging in the classroom still actively incorporate all of their linguistic resources in their coursework. Any way one views it, though, if students do not appreciate translanguaging practices being incorporated in their classrooms, then the idea of trying to help them via such measures is somewhat counterproductive.

To illustrate the importance of student receptiveness, Milson-Whyte (2013) poses an interesting counter-perspective for the use of translanguaging in the classroom, grounded in student attitude. Milson-Whyte acknowledges that some writers may not want to employ translingual techniques either because they are used to the standard of writing due to their 
working with it for their academic careers previously or because they deem they can determine when utilizing translanguaging is too much extra work. Considering the arduous mental toll that such awareness can take on students, we feel it would make sense to assume that some would not want to bother adding another set of academic responsibilities to their workloads.

Thus, it can be argued that information regarding student response to translanguaging in the classroom (particularly at the university level where students are arriving after experiencing teaching which separates languages) is essential for student success, yet often overlooked. As a result, this study will focus on adding to this limited body of literature, seeking to determine if students are receptive to a pedagogy that strategically incorporates translanguaging practices in the classroom.

\section{Research Context}

\section{History}

The UPRM campus was established in 1911 as a land-grant university ("Information about UPRM," n.d.). The current generation of college students is one that has grown up in a mostly bilingual environment, but which is likely more comfortable and more fluent in Spanish than English since Spanish is the language of everyday communication in Puerto Rico. Once students enter the Puerto Rican university setting, a working knowledge of the English language is expected, and in some cases, explicitly required.

\section{English in the Classroom}

Prior to admission at UPRM, students are instructed as to their need for a certain level of bilingualism. The admission standards say, "Spanish is the language of instruction in most courses at UPRM, but students are required to have a working knowledge of the English language [and] the individual professor decides the language used in lectures and in student evaluation activities" ("University of Puerto Rico," n.d., p. 75). Further, once accepted to any program, students must meet a minimum of 12 required credits in English They complete a basic, intermediate, or advanced sequence depending on the level of proficiency demonstrated by the student on a standardized exam ("Department of English," n.d.).

At UPRM, the home language of the vast majority of students is Spanish. Even if students are permitted to use Spanish in the English classroom, though, the work they complete must be solely in English. Beyond the English classroom, though, the English language finds its way into other courses and English-language texts are frequently utilized in classes that are not specifically teaching English (Mazak \& Herbas-Donoso, 2014). 


\section{Classroom Translanguaging}

Whether it is intentional or not, a certain degree of translanguaging happens in numerous classrooms at UPRM. Puerto Rican science classrooms have been proven to use multiple languages in creative ways, possibly due to the use of English language course materials. This could be attributed to the presumption that English is the language of science, though there is nothing inherently scientific about the language that should give it preference over any other language (Mazak \& Herbas-Donoso, 2014). However, even amidst classes entirely in Spanish, key terms in English are sometimes used in discourse (Mazak \& Herbas-Donoso, 2014). At UPRM, it was reported by multiple professors that, while they will sometimes use terminology in English, they will also present an explanation in Spanish for the students' benefit (Mazak \& Herbas-Donoso, 2014). Bilingual course materials, such as handouts, exams, and PowerPoint presentations, support this integration, which shows translanguaging practices in the classroom extending beyond spoken discourse. Beyond that, when it is possible or deemed necessary, the English translations are maintained and taught, specifically for the purposes of key terminology and acronyms, the latter of which potentially risk being rearranged in the translation process (Mazak \& Herbas-Donoso, 2015). While this phenomenon is something that occurs in Puerto Rican classrooms, the students' attitudes towards this have yet to be reported.

\section{Method}

The purpose of the present analysis is to draw tentative conclusions regarding the role of student attitude in translanguaging perceptions and receptiveness using case study methodology. The data were collected by a research team with permission (received prior to the start of this study) from the Institutional Review Board (IRB) of the UPRM, with data collection taking place in an upper-level undergraduate class in abnormal psychology over one academic semester. Participation was voluntary throughout the duration of the study and students could opt out at any point during the semester.

The case reported on in this study is an upper-level abnormal psychology class at the UPRM, which was a required course for all psychology majors. This particular classroom was an interesting case for several reasons: most notably because (1) the textbook was in English while the course was conducted in a bilingual manner, and (2) because of the instructor's classroom language practices. The instructor, a native English speaker who speaks Spanish as a second language, offers her students a choice of which language they prefer to use. To supplement course materials and discussion, she used both English and Spanish in the classroom, often in very close proximity or even mixed. The analysis takes into account student opinions regarding this flexibility and freedom to engage in translanguage. 
Our study seeks to provide an answer to the following research questions:

1. How is translanguaging used in this Puerto Rican psychology classroom?

2. How do these students respond to the implementation of a flexible bilingual pedagogy?

3. What broader conclusions can be drawn from these students' answers?

As a case study, this project sought deeply to describe the particularities of language use in the selected classroom. The data reported here were part of a larger set of data collected in the case which included classrooms observations, collection of student- and teachercreated materials (exams, handouts, etc.), and surveys. Here we exclusively report the results of the two surveys distributed as part of the larger case study. The first survey, the Language Attitude Survey, dealt with the students' attitudes towards language mixing, both in class and in their everyday lives. This survey asked a series of yes or no questions as well as several open-ended questions, the latter of which students tended to ignore. However, the most impactful and useful information which was acquired came from a series of questions asked on a one to four Likert scale. These questions asked about students' feelings and perceptions regarding the professor's code switching, with four being the most positive (i.e., appropriate) and one being the least positive (i.e., inappropriate).

The second survey, the Student Background Survey, asked questions regarding the students' personal experiences and their linguistic development, including the language of discourse at home and with influential figures in their lives (parents, friends, etc.). While a few open-ended questions were included, this survey primarily contained questions on a one to five Likert scale, with a one rating being the least positive, the five rating being the most positive, and a three rating being neutral.

For both surveys, the most pertinent information came from analysis of the Likert scale questions, as these questions most clearly informed us on the students' attitudes towards language mixing and the professor's pedagogical choices.

\section{Data Analysis}

Analysis of collected surveys helped the researchers draw general conclusions about the success (or lack thereof) of translingual pedagogy in this particular classroom. The students' background information was also explored via the surveys, which included questions regarding the students' linguistic histories and educational background. Surveys were distributed on the day of the final exam, after students had completed the exam. A total of 29 students (24 female and 5 male) completed the Language Attitudes Survey, slightly 
fewer (26 students) completed the Student Background Survey. Completion of the surveys was optional and perhaps due to time constraints fewer students answered the second survey.

As previously stated, the Likert scale questions were deemed most relevant for determining the students' attitudes towards the instructor's pedagogical choices. When compiling their general attitudes as expressed on the survey, their numerical responses were added up and totaled, then divided by the number of student respondents who participated (as some students opted out of answering all questions, and some students did not complete each survey). This ultimately provided us with percentages from which we could more easily draw conclusions.

Because ours was a case study, we were not looking for causal relationships between variables in students' answers to the survey. Rather, the numerical representations of the data from the two surveys are purely descriptive.

\section{Results and Discussion}

\section{Participant Data}

Age. The 29 student respondents ranged in age from 20 to 25 years old. The average age was 22.5 years, with the median age being 23 . When divided along gender lines, the average age remained roughly the same; for the 24 females, the average age was 22.5 years and the average age of the 5 males was 22.4 years. The most frequently occurring age was 23 years old, with 9 of 29 students reporting this. This was a class of students of a similar age, with similar linguistic competencies.

Self-assessed comfort with languages. The vast majority of the student participants surveyed reported a high level of confidence with the Spanish language. On the Student Background Survey, a question was posted regarding the students' comfort level with the languages. On a scale of one to four, with one indicating that the respondent "only knows some words or expressions" and four showing the respondent is "confident in extended conversations," $79 \%$ of the students (23 out of 29 ) responded with a four rating; and, in total, $96 \%$ of the students responded with a three or four, with only one respondent giving a two rating. Thus, it is clear that, as one may expect, students surveyed are confident in their Spanish skills.

The distribution for the English comfort level is a bit more spread out. While $82 \%$ of the class gave themselves a three or a four rating on the same scale, $34 \%$ of the class gave themselves a rating of three, stating that they are "fairly confident in basic conversations." This was twice as many students as those who assessed their Spanish competence with a three rating. Seventeen percent of the class rated their comfort level as two, indicating they are only "confident in basic conversations." While the spread of English comfort still falls on the higher range of the spectrum, there is a clear discrepancy in comfort and perceived English-language competence, 
which may adversely impact student perceptions of English-Spanish code-switching as well as the use of English language texts in an otherwise Spanish language classroom.

\section{Survey Data}

The Language Attitude Survey asked several questions pertaining to the students' views on the instructor's code switching within the class. One such question identified 16 different adjective options to describe the instructor's use of English-Spanish code switching in the classroom (i.e., modern vs. old-fashioned, positive vs. negative) and asked students to rate them on a one to four Likert scale. For this survey, one was the most positive answer and four were the most negative. The one to four scale prevented a neutral response; students had to deem the characteristic in question as either positive or negative.

These data were reviewed and some of the more pertinent questions identified for further inquiry and review. A previous question asked students to identify their stronger language, with the choices being "Spanish," "English," or "both." Forty-eight percent of students stated that Spanish was their stronger language, $7 \%$ of students said English, and $41 \%$ identified themselves as having equal proficiency in both languages. This classification was used to divide the students in order to determine if students of a particular category had consistency in their perceptions of translanguaging.

Appropriate vs. inappropriate. The first question which asked of students was whether they viewed the instructor's code-switching as appropriate or inappropriate. The instructor's use of translingual pedagogy within the classroom was largely deemed appropriate. The responses were split equally between this approach being "appropriate" (a two ranking) and "very appropriate" (a one ranking), with thirteen students in each category. No significant differences between those who identified as Spanish-dominant, English-dominant, or equally skilled in both languages emerged, though both of the English-dominant students gave two rankings for this question. Regardless, this question shows that the student population, almost across the board, deems the instructor's translanguaging as an appropriate method of facilitating classroom discussion and communication.

Normal vs. strange. It is possible that, if translanguaging is seen as unique or unusual, students will be taken aback by its use in the classroom. For this reason, it is important to inquire as to whether or not the use of pedagogical translanguaging is viewed as normal or strange for the students who are receiving such instruction. Fifty-one percent of the students deemed the code switching to be "very normal"; $33 \%$ of them stated that this phenomenon was "normal." Only one student indicated this phenomenon was strange. Interestingly, over half of the students who responded to this question most positively were those who self-identify as being equally proficient in both languages. Their relation to the 
normalness of such code switching may signal that they themselves employ such methods of communication in their daily lives, thus taking away some of its strangeness.

Social acceptability vs. non-acceptability. This question somewhat speaks to the normalness/strangeness of code switching, and likely informed some of the student responses which were received. If code switching is socially acceptable in one's daily life, it is very likely that it will be viewed as a normal occurrence. As such, one would assume the answers to this question would fall in line with the previous question, at least to some degree. Somewhat true as regards this prediction, the results of this question were fairly similar to the previous question regarding normalcy: Fifty-six percent of the respondents gave this a one rating, indicating this is a very acceptable phenomenon; $30 \%$ of the students gave a two rating; and only one student with equal proficiency in both languages gave this a three rating, indicating a lack of social acceptability. The most positive responses, again, were dominated by students reporting equal proficiency in both English and Spanish. The class appeared to be very accepting of the code switching as both a normal and socially acceptable phenomenon, indicating that there should not have been an affective filter regarding the strangeness of the instructor's language mixing.

Respectful vs. disrespectful. An action can be socially acceptable while still being perceived as disrespectful. If the instructor's code switching is perceived as disrespectful to the students, then it is likely that they will be less inclined to receive her message favorably or to incorporate such language mixing in their own lives. Thus, this question sought to determine whether students viewed the instructor's code switching as respectful or disrespectful. The distribution seen in this question was somewhat different from those previously discussedstudents were still generally favorable in their views of translanguaging as respectful, but they were not as firm in their beliefs. More students gave a two rating here than on any other question (48\%). However, overall, respondents were on the positive end of the spectrum, with only two respondents stating the code switching was "disrespectful," in the form of a three rating.

Professional vs. unprofessional. The answer with the most distribution in the students' responses, interestingly, deals with whether the professor's translanguaging was "professional." An instructor's professionalism directly impacts his or her ethos/credibility; if an instructor is viewed as less than professional, he or she will not be respected as an expert or as someone worthy of listening to and learning from. Students were generally positive in their answers, with $59 \%$ of them rating this one or a two, but unlike other questions, the results were more spread out among the available options. This question featured the most dissention in the student answers received, as well as the largest number of negative responses, with 14\% giving a three rating of "unprofessional," and 11\% giving a four rating for being "very unprofessional." It is interesting to note that, while students largely replied 
that the code switching was a positive trait of the class, it may not have been the most "professional" way for the professor to undertake her job of teaching.

Clarifying vs. confusing. Arguably, more than anything else, it is important to determine whether code switching and translanguaging are viewed as a tool for clarification, or whether they confuse students. If the purpose of such translingualism in the classroom is to offer greater student understanding, it is crucial that this goal gets met. While the student respondents generally held favorable views towards the use of translanguaging as a clarifying tool, many more students rated this on the lower end of the scale. Sixty-seven percent of student respondents answered with a one or a two (with most answering two), and the remaining students answered with a three rating. No student reported that translanguaging was a very confusing occurrence, and the Spanish-dominant students generally indicated favorable views towards the instructor's translingual tactics in the classroom.

Positive vs. negative. Overall, it is important to determine whether students viewed the use of code switching and translanguaging in the classroom as a positive feature of the class. The students are the ones who experience this class for a minimum of 45 contact hours and who must interact with and seek clarification from the instructor, so their comfort and feelings of positivity are of utmost importance in this situation. In total, student views of the instructor's translanguaging were generally positive, with virtually all respondents (85\%) answering with a one or a two rating. Only one Spanish-dominant student responded with a three rating for "somewhat negative." This may suggest that the clarification offered by the instructor's translanguaging was, to some extent, helpful to them.

Overall code-switching preferences in the classroom. Even more telling than student perceptions of positivity and negativity is explicitly asking them whether they would like professors to code-switch in the classroom. The phrasing of the question asked students if they would like professors of other disciplines (i.e., math, physics, biochemistry) to codeswitch between English and Spanish as needed. The results of this survey can be seen in Figure 1.

For the most part, students were indifferent to code switching in the classroom, as indicated by the survey. This can be taken in one or two ways: one, that they genuinely do not care which language(s) they are instructed in, or two, that they can survive and thrive in both an either-or and a both-and environment of language use. Either way, with more than half of this class falling in the "does not matter" category, their motivations are something worth considering, yet we are ultimately unsure of why the instructor's translingual pedagogy does not matter.

In general, students were positive towards the use of translanguaging in other disciplines. Interestingly, the distribution of students who identify as Spanish-dominant and having proficiency in both languages were somewhat even in the "yes" and "does not matter" 


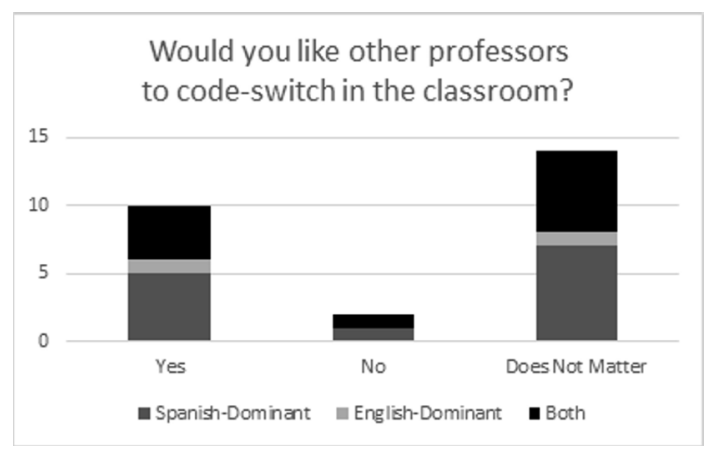

Figure 1. Expressed Student Attitudes on Language Mixing in Other Courses

categories. Theoretically, this would make it difficult to predict whether a student's language expertise or knowledge plays a role in their comfort with pedagogical translanguaging, at least as reported on this particular survey.

Student perceptions of language mixing. Two questions of the Language Attitude Survey were dedicated to determining the students' judgment on the use of translanguaging in their own daily lives. This survey was different, though, in that students were not asked about their dominant language, so a division of results based on these criteria is not possible. Thus, students were instead categorized as male and female for these results.

Students were first asked about their feelings in the statement "In everyday conversations, I keep the Spanish and English languages separate." Their responses were gauged on a one to

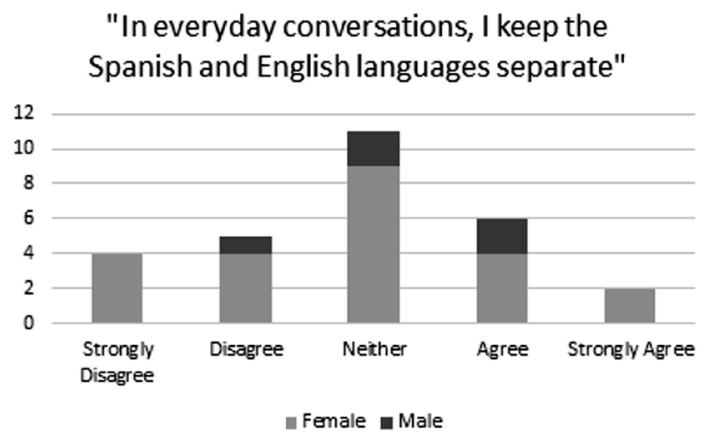

Figure 2. Student Attitudes on Language Mixing in Their Daily Lives 


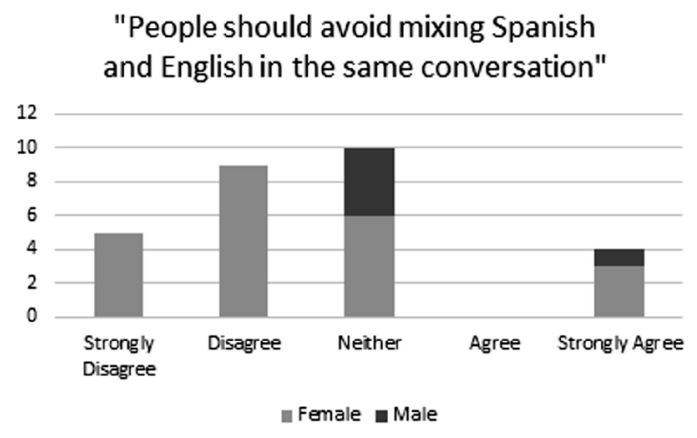

Figure 3. Student Attitudes on Language Mixing in Society

five spectrum from "strongly disagree" to "strongly agree," with a three indicating a neutral "neither." These results can be seen in Figure 2.

The results seen in Figure 2 were very interesting, considering there were roughly the same amount of students on the positive and negative ends of the spectrum. The largest number of respondents indicated that they had no opinion (the neutral response), which could ultimately be counted either way. These results can be seen in Figure 3.

In general, students disagreed with this sentiment. Even if all of the students who reported not having an opinion on this question were included with the students who "strongly agree," the number of respondents is still roughly equal to the number of students who either "disagree" or "strongly disagree." There is a wider distribution in answers than one may expect in looking at the question; however, considering the amount of students who speak both languages, it is somewhat surprising that so many of them hold these prescriptive standards for how the languages should be used.

\section{Overall Student Perceptions}

Students were, for the most part, positive in their answers to the questions discussed. The consensus was that the instructor's code switching was appropriate, normal, and respectful, among a series of other answers. However, it is notable to consider that two questions with the largest amount of dissent in answers, though, concerned regarding the clarifying power and professionalism of the instructor's code switching. If the purpose of her code switching was almost certainly to offer further clarification for her students, it missed the mark for about $1 / 5^{\text {th }}$ of the respondents. 


\section{Conclusions: Limitations and Implications}

Previous studies have found that students perceive English to be "very important, whether in terms of its general use or its use in education" (Klapwijk \& Van der Walt, 2016, p. 72), with home and native languages being less prized by comparison. As a result, the home language is often used as a stepping-stone of sorts (Sayer, 2013); it is used to allow students to keep learning content matter while acquiring the English language and, once they have satisfactorily done so, they get moved into mainstream classrooms. For multilinguals, one language may be associated with family, home life, and community, while another may be viewed as being more important for social and professional mobility and, in most cases, the latter language is English. This difference in language attitudes can cause a discrepancy in how languages are treated in the classroom.

Other studies have focused on the attitudes of multilingual students towards learning in strictly English-medium classrooms; also, whether these students approve or disapprove of such pedagogical choices (Muthanna \& Miao, 2015). Ultimately, though, as BrockUtne (as cited in Klapwijk \& Van der Walt, 2016, p. 68) states, "education should be about acquiring knowledge, and not merely about learning English." One of the best ways to enact this ideology is through translanguaging, though if students are not receptive to such a pedagogical choice, then it may be doomed from the start.

One can see from this study that this particular group of students in the context of Puerto Rico has a generally neutral to positive outlook on translanguaging in the classroom. Indeed, on many questions, the most frequently indicated answer was the most neutral answer, as can be seen in the questions that directly pertained to student language attitudes. The high number of neutral responses could mean that students are indifferent to translingual pedagogy or that they could survive with or without it. A more likely interpretation is that these students are conditioned to work within a context where code switching and translanguaging happens on a frequent basis, and thus, the instructor's choice of implementing translingual pedagogy is nothing unusual.

As seen both in previous work by Mazak and Herbas-Donoso (2014, 2015), and in this study as well, for this particular context, translanguaging is common and happens in virtually all classes. Whether or not the students' linguistic practices mesh with their stated attitudes, particularly for those who follow a more monolingual pattern of beliefs regarding keeping languages separate and avoiding code switching and translanguaging, is a matter for further inquiry. It is possible that students were answering what they felt they "should" say, rather than what they actually do in this context. As seen in Kircher's (2016) study of multilingual students, participants from three different L1 groups spoke on the perceived importance of English; all three groups noted that English is "significantly better suited to modern society [and] significantly more likely to increase their opportunities to find employment" (p. 251). It is not a stretch of the imagination to assume that these attitudes that favor English would be widespread among speakers of all languages in today's globalized world. 
Self-identified proficiency in language did not appear to play a role in student satisfaction with translingual classroom practices; various answers had similar numbers of student respondents from the English-dominant, Spanish-dominant, and equally proficient demographics. Thus, it could be said that one's receptiveness to translingual pedagogy is a matter informed by one's previous educational experiences and the language attitudes that were formed along their educational journey. One can see that educational planning can be highly successful when taken at a "grassroots" level that accounts for student attitudes towards language in education (Kircher, 2016, p. 244). Taking these stigmas, feelings, and attitudes into account before the students even enter the classroom can ultimately determine whether a translingual pedagogy is set up for success or failure.

Overall, however, the current body of research is limited on the amount of impact that translingual measures have on student success, but it would be interesting to see how future research can further validate this pedagogy. It would be wise for translingual-minded instructors, when creating course materials, to seek to create more of a balance between the subtler elements of such presentations, both for the sake of the students who are subliminally picking up on such messages and for opponents of translingual strategies looking for ways to discredit such approaches as favoring the native language as a crutch rather than a learning tool.

In order to implement strategic translanguaging in the classroom, one would need to first counteract the idea of translanguaging in the classroom as being conducive to student laziness and underachievement in a bilingual education setting which is unfortunately fairly prevalent in the literature to date. While there is a limited body of research on this topic at present, with more insight and interrogation into the topic, translanguaging can be a useful pedagogical decision to make rather than something extremely intimidating or misunderstood.

\section{References}

Canagarajah, A. S. (2013). Negotiating translingual literacy: An enactment. Research in the Teaching of English, 48(1), 40-67.

Census 2010 total population. (n.d.). American FactFinder [website]. Retrieved from http://factfinder2.census.gov/faces/nav/jsf/pages/community_facts.xhtml.

Department of English, University of Puerto Rico: Mayagüez. (n.d.). [website]. Retrieved from http://www.uprm.edu/english/?q=node/27

García, O., \& Li, W. (2014). Translanguaging: Language, bilingualism, and education. New York, US: Palgrave Macmillan. https://doi.org/10.1057/9781137385765.

García, O., \& Sylvan, C. E. (2011). Pedagogies and practices in multilingual classrooms: Singularities in pluralities. The Modern Language Journal, 95(3), 385-400. https://doi.org/10.1111/ j.1540-4781.2011.01208.x. 
Kircher, R. (2016). Language attitudes among adolescents in Montreal: Potential lessons for language planning in Quebec. Nottingham French Studies, 55(2), 239-259. https://doi.org/10.3366/ nfs.2016.0151.

Klapwijk, N., \& Van der Walt, C. (2016). English-plus multilingualism as the new linguistic capital? Implications of university students' attitudes towards language of instruction in a multilingual university. Journal of Language, Identity, and Education, 15(2), 67-82. https://doi.org/10.10 80/15348458.2015.1137475.

Mazak, C. M., \& Herbas-Donoso, C. (2014). Translanguaging practices and language ideologies in Puerto Rican university science education. Critical Inquiry in Language Studies, 11(1), 27-49. https://doi.org/10.1080/15427587.2014.871622.

Mazak, C. M., \& Herbas-Donoso, C. (2015). Translanguaging practices at a bilingual university: A case study of a science classroom. International Journal of Bilingual Education and Bilingualism, 18(6), 698-714. http://doi.org/10.1080/13670050.2014.939138.

Michael-Luna, S., \& Canagarajah, A. S. (2008). Multilingual academic literacies: Pedagogical foundations for code meshing in primary and higher education. Journal of Applied Linguistics, 4(1), 55-77.

Milson-Whyte, V. (2013). Pedagogical and socio-political implications of code-meshing in classrooms: Some considerations for a translingual orientation to writing. In A. S. Canagarajah (Ed.), Literacy as translingual practice: Between communities and classrooms (pp. 115-127). New York, US: Routledge.

Muthanna, A., \& Miao, P. (2015). Chinese students' attitudes towards the use of English-medium instruction into curriculum courses: A case study of a national key university in Beijing. Journal of Education and Training Studies, 3(5), 59-69. https://doi.org/10.11114/jets.v3i5.920.

Sayer, P. (2013). Translanguaging, TexMex, and bilingual pedagogy: Emergent bilinguals learning through the vernacular. TESOL Quarterly, 47(1), 63-88. https://doi.org/10.1002/tesq.53.

University of Puerto Rico, Mayagüez Campus. (n.d.). Undergraduate catalogue 2014-2015. Retrieved from http:/ /www.uprm.edu/cms/index.php?a=file\&fid $=7081$.

\section{The Authors}

Adrian J. Rivera graduated from the University of Puerto Rico (Mayaguez) with a Master's in English Education in 2015. He is a Limited Term Lecturer of English Indiana University-Purdue University, Fort Wayne, as well as the ESOL Tutor at Ivy Tech Community College, Fort Wayne.

Catherine M. Mazak is co-director of CeIBA (Centro para la investigación del bilingüismo y aprendizaje [Center for research on bilingualism and learning]) and associate professor of English at the University of Puerto Rico, Mayagüez. She studies bilingualism and translanguaging practices in higher education using ethnographic research methods. 